\title{
ProBlematyKa PODZiAŁU MAJĄTKU POLIKWIDACYJNEGO SPÓŁKI Z O.O. ZE SZCZEGÓLNYM UWZGLĘDNIENIEM ZAGADNIENIA WYDANIA JEGO SKŁADNIKÓW W FORMIE RZECZOWEJ W ŚWIETLE PRAWA PODATKOWEGO
}

\begin{abstract}
Streszczenie. $W$ artykule zostało przeanalizowane zagadnienie podziału majątku polikwidacyjnego spółki z o.o. pomiędzy jej wspólników, ze szczególnym uwzględnieniem problematyki wydania jego składników w formie rzeczowej. Przyczynkiem do analizy niniejszego zagadnienia była niejednolita linia orzecznicza sądów administracyjnych w zakresie uznania, czy czynność wydania majątku polikwidacyjnego w formie rzeczowej prowadzi do powstania po stronie spółki przychodu. Autorka skupia się zarówno na regulacjach prawa podatkowego, jak też prawa handlowego oraz zasad rachunkowości w odniesieniu do tej kwestii.
\end{abstract}

Słowa kluczowe: podatek dochodowy od osób prawnych, likwidacja spółki kapitałowej, świadczenie $w$ formie niepieniężnej.

* Uniwersytet Warszawski, Wydział Prawa i Administracji. Laureatka VII Edycji Programu Diamentowy Grant, email: aleksandra.tychmanska@gmail.com 
Przedmiotem artykułu jest analiza zagadnienia podziału majątku polikwidacyjnego spółki z o.o. pomiędzy jej wspólników, ze szczególnym uwzględnieniem problematyki wydania jego składników w formie rzeczowej. Regulacja tego zagadnienia stwarza szczególnie poważne problemy w prawie podatkowym powodując istotne wątpliwości interpretacyjne w zakresie uznania czy czynność wydania majątku polikwidacyjnego $\mathrm{w}$ formie rzeczowej prowadzi do powstania po stronie spółki przychodu. W związku z tym artykuł skupia się w szczególności na przestudiowaniu, jak przedmiotowa materia uregulowana została w prawie podatkowym. Analizując podatkowe skutki wydania majątku polikwidacyjnego, warto jednak przyjrzeć się także temu, jak niniejsze zagadnienie jest ujęte w przepisach prawa handlowego oraz $\mathrm{w}$ przepisach $\mathrm{z}$ zakresu rachunkowości, co pozwoli ukazać analizowaną materię w szerszej perspektywie.

\section{Podatkowe SKutKi WYdAnia MająTKu POLiKWidacyjnego}

W FORMIE RZECZOWEJ

Zgodnie z art. 14a ustawy z dnia 15 lutego 1992 r. o podatku dochodowym od osób prawnych ${ }^{1}$, w sytuacji gdy podatnik przez wykonanie świadczenia niepieniężnego reguluje w całości lub w części zobowiązanie - w tym z tytułu zaciągniętej pożyczki (kredytu), dywidendy, umorzenia albo zbycia w celu umorzenia udziałów (akcji) - przychodem takiego podatnika jest wysokość zobowiązania uregulowanego w następstwie takiego świadczenia. Regulacja ta jest źródłem licznych wątpliwości interpretacyjnych. Można zasadniczo wyróżnić dwie grupy stanowisk: (1) te uznające, że wydanie majątku likwidowanej spółki jej wspólnikom prowadzi do powstania przychodu do opodatkowania po stronie spółki - w związku z tym, że wydanie majątku polikwidacyjnego $\mathrm{w}$ formie rzeczowej stanowi spełnienie zobowiązania spółki względem jej wspólników² ${ }^{2}$ oraz (2) te oparte na przekonaniu, że czynność ta nie może prowadzić do powstania przychodu po stronie spółki - w tym przypadku wysuwane są różne argumenty na poparcie tej tezy.

${ }^{1}$ Dz.U. z 2018 r., poz. 1036 z późn. zm.; dalej: u.p.d.o.p.

${ }^{2}$ Por. wyrok WSA we Wrocławiu z dnia 16 listopada 2015 r., I SA/Wr 1563/15, Lex nr 2042239. 
2.1. Poprzedni stan prawny i możliwość powstania przysporzenia po stronie podmiotu spełniającego świadczenie zamienne

Na wstępie prowadzonych rozważań należy zaznaczyć, że spór o opodatkowanie czynności wydania majątku polikwidacyjnego w formie rzeczowej po stronie spółki istniał jeszcze w poprzednim stanie prawnym, przed wprowadzeniem art. 14a. W celu opisania wydania majątku polikwidacyjnego w formie rzeczowej sądy administracyjne odwoływały się do konstrukcji datio in solutum (świadczenie w miejsce wypełnienia). Instytucja ta została uregulowana w art. 453 ustawy z dnia 23 kwietnia 1964 r. Kodeks cywilny ${ }^{3}$. Zgodnie z tym przepisem, „jeżeli dłużnik w celu zwolnienia się ze zobowiązania spełnia za zgodą wierzyciela inne świadczenie, zobowiązanie wygasa".

Organy podatkowe oraz część składów orzekających stojących na stanowisku, że czynność ta powinna podlegać opodatkowaniu, uzasadniając tę tezę, wskazywały na treść art. 12 ust. 1 u.p.d.o.p., podkreślając, że katalog ujętych w nim przychodów ma charakter otwarty, oraz na art. 14 u.p.d.o.p., który określał sposób ustalania wielkości przychodu będącego następstwem zbycia rzeczy lub praw majątkowych. Zaznaczano, że czynność ta jest odpłatna, ponieważ podmiot otrzymuje korzyść w postaci zmniejszenia się jego zobowiązania ${ }^{4}$. Ponadto „,cena nie zawsze musi być wyrażona w pieniądzu. Może również przybrać postać zwolnienia danego podmiotu (dłużnika) z ciążących na nim zobowiązań wobec innego podmiotu"5. Podkreślano, że czynność prawna jest odpłatna w sytuacji, gdy podmiot, który dokonał przysporzenia, otrzymuje w zamian korzyść majątkową stanowiącą ekwiwalent tego przysporzenia - w omawianym przypadku poprzez zbycie majątku polikwidacyjnego spółka otrzymuje ekwiwalent w postaci zmniejszenia się jej zobowiązań ${ }^{\text {. }}$

Większość sądów administracyjnych zajęła jednak odmienne stanowisko w przedmiocie podatkowych skutków wydania majątku polikwidacyjnego. Wskazywały one, że datio in solutum jest formą zaspokojenia zobowiązania i co do zasady nie powoduje żadnego przysporzenia po stronie

${ }^{3}$ Dz.U. z 2018 r., poz. 1025 z późn. zm.; dalej: k.c..

${ }^{4}$ Z uzasadnienia wyroku WSA w Warszawie z dnia 4 lipca 2012 r., III SA/Wa 2075/12, Lex nr 1330653.

${ }^{5}$ Interpretacja indywidualna z dnia 22 października 2013 r., IPTPB3/423-297/13-2/MF.

${ }^{6}$ Interpretacja indywidualna $\mathrm{z}$ dnia 9 marca 2012 r., IPPB3/423-1053/11-2/DP. 
spełniającego świadczenie dłużnika7. Wydanie majątku polikwidacyjnego nie stanowi wykonania przez spółkę umowy dwustronnie zobowiązującej, prowadzi ono jedynie do wygaśnięcia zobowiązania spółki względem wspólnika, zaś udziałowiec nie będzie zobowiązany wykonać na rzecz spółki jakiegokolwiek świadczenia wzajemnego ${ }^{8}$. Ponadto podkreślano, że tak jak zwolnienie z długu stanowi przysporzenie dłużnika z tytułu darowania mu długu, tak tych samych skutków nie można przypisać datio in solutum, które ściśle wiąże wygaśnięcie zobowiązania z zaspokojeniem wierzyciela. Zwolnienie $\mathrm{z}$ długu jest bowiem przysporzeniem dłużnika wskutek darowania mu długu?.

Istotnym głosem w dyskusji było wskazanie na ogólną zasadę prawa podatkowego, zgodnie z którą ta sama czynność nie może wywoływać obowiązku podatkowego u dwóch stron tej czynności ${ }^{10}$. Zgodnie zaś z art. 17 ust. 1 pkt 4 lit. c ustawy z dnia 26 lipca 1991 r. o podatku dochodowym od osób fizycznych ${ }^{11}$, opodatkowaniu podlega przychód uzyskany z tytułu podziału majątku likwidowanej osoby prawnej lub spół$\mathrm{ki}^{12}$. Tak więc $\mathrm{w}$ tym przypadku z ustawy podatkowej wynika wprost, że w związku z wydaniem majątku polikwidacyjnego przez spółkę jej wspólnikom po stronie wspólników powstaje przychód do opodatkowania. Przychodem podatkowym może być wartość charakteryzująca się definitywnym przyrostem majątku podatnika, zaś w tym przypadku czynność ta nie prowadzi do zwiększenia majątku samej likwidowanej spółki, natomiast powoduje pozbawienie jej majątku (jej aktywa netto ulegają zmniejszeniu $)^{13}$. W wyroku z dnia 8 lutego 2012 r. Naczelny Sąd Administracyjny podkreślił natomiast, że „,wypłata z zysku w formie rzeczowej

${ }^{7}$ Wyrok Naczelnego Sadu Administracyjnego z dnia 28 stycznia 2015 r., II FSK 2083/13, Lex nr 1646209.

${ }^{8}$ Interpretacja indywidualna $z$ dnia 23 lutego 2018 r., IPPB3/423-899/13-3/S/DP/MC.

${ }^{9}$ Wyrok Naczelnego Sadu Administracyjnego z dnia 16 lutego 2018 r., II FSK 385/16, Lex nr 2468011.

${ }^{10}$ Por. wyrok Naczelnego Sądu Administracyjnego z dnia 20 lipca 2017 r., II FSK 1641/15, Lex nr 2324701.

${ }^{11}$ Dz.U. z 2018 r., poz. 200 z późn. zm.

${ }^{12}$ Również odpowiednio w u.p.d.o.p.: art. 7b ust. 1 pkt 1 lit. e („Za przychody z zysków kapitałowych uważa się przychody z udziału w zyskach osób prawnych, z zastrzeżeniem art. 12 ust. 1 pkt 4b, stanowiące przychody faktycznie uzyskane z tego udziału, w tym wartość majątku otrzymanego w związku z likwidacją osoby prawnej lub spółki, o której mowa w art. 1 ust. 3 ”).

${ }^{13}$ Interpretacja indywidualna $z$ dnia 23 lutego 2018 r., IPPB3/423-899/13-3/S/DP/MC. 
spowoduje przesunięcie danej pozycji z aktywów na pasywa w bilansie spółki. Nie powstanie jednak z tego tytułu żadne przysporzenie majątkowe, a więc przychód podatkowy w spółce" ${ }^{14}$.

Instytucja datio in solutum była wykorzystywana w procesach restrukturyzacyjnych, przykładowo przy wypłacie dywidendy, umorzeniu udziałów czy regulowaniu pożyczek, stając się równocześnie sposobem na optymalizację podatkową. Przykładowo, gdy spółka wypłacała dywidendę w formie rzeczowej, w rzeczywistości spełniała swoje zobowiązanie. Oszczędność podatkowa polegała na tym, że gdyby spółka chciała sprzedać składnik aktywów, wiązałoby się to z koniecznością rozpoznania przez spółkę przychodu podatkowego na gruncie u.p.d.o.p. Natomiast w sytuacji, gdy spółka wypłacała wspólnikowi dywidendę w formie rzeczowej, przenosząc na niego składniki aktywów, zwalniała się ze zobowiązania z tytułu dywidendy oraz zbywała składnik majątku, nie wykazując przychodu z odpłatnego zbycia. Dominowała linia orzecznicza uznająca, że spółka wydając rzecz jako dywidendę, reguluje tylko swoje zobowiązanie, niczego w zamian nie otrzymując, w związku z czym nie można mówić o powstaniu przychodu po stronie spółki ${ }^{15}$.

\subsection{Obecny stan prawny}

W związku ze sporem dotyczącym tego, w jaki sposób należy podatkowo traktować regulowanie zobowiązań po stronie spełniającego świadczenie $\mathrm{w}$ formie niepieniężnej, ustawą z dnia 29 sierpnia 2014 r. o zmianie ustawy o podatku dochodowym od osób fizycznych oraz niektórych innych ustaw ${ }^{16}$ ustawodawca zdecydował się wprowadzić do u.p.d.o.p. art. 14a. Nowa regulacja zaczęła obowiązywać od 1 stycznia 2015 r. Nie rozwiała jednak wątpliwości interpretacyjnych, ponieważ nowo wprowadzony przepis wśród przykładowych świadczeń niepieniężnych, których wykonanie reguluje w całości lub w części zobowiązanie, nie wymieniał wydania majątku polikwidacyjnego w formie rzeczowej.

${ }^{14}$ Wyrok Naczelnego Sądu Administracyjnego z dnia 8 lutego 2012 r., II FSK 1384/10, Lex nr 1104752.

${ }^{15}$ Por. wyrok Naczelnego Sadu Administracyjnego z dnia 8 lutego 2012 r., II FSK 1384/10, Lex nr 1104752; wyrok Naczelnego Sadu Administracyjnego z dnia 22 lutego 2013 r., II FSK 1771/11, Lex nr 1277934.

${ }^{16}$ Dz.U. z 2014 r., poz. 1328 ze zm. 
Pewna wskazówka interpretacyjna została zawarta w uzasadnieniu do projektu ustawy proponującego wprowadzenie do u.p.d.o.p. artykułu $14 \mathrm{a}^{17}$. Można było z niej wywnioskować, że intencją ustawodawcy było ujednolicenie skutków podatkowych występujących po stronie spółki w związku $\mathrm{z}$ regulowaniem $\mathrm{w}$ formie rzeczowej zobowiązań wobec wspólnika $\mathrm{z}$ tytułu m.in. likwidacji spółki oraz opodatkowania czynności przekazania majątku w formie rzeczowej. Podstawę tego założenia stanowił następujący fragment uzasadnienia projektu ustawy: „,...] przyczyną podjęcia kwestii ustalania wartości przychodów i kosztów świadczeń w naturze jest niejednolita linia orzecznicza sądów administracyjnych w sprawach dotyczących m.in. skutków podatkowych występujących po stronie spółki w związku $\mathrm{z}$ regulowaniem $\mathrm{w}$ formie rzeczowej zobowiązań wobec wspólnika $\mathrm{z}$ tytułu należnej dywidendy, umorzenia udziałów, likwidacji spółki”.

Pierwsza linia orzecznicza, uznająca, że wydanie majątku likwidowanej spółki jej wspólnikom prowadzi do powstania przychodu do opodatkowania po stronie spółki, z reguły wskazywała na czysto doprecyzowujący charakter art. 14a u.p.d.o.p. ${ }^{18}$. Wpisując przekazanie majątku polikwidacyjnego $\mathrm{w}$ formie rzeczowej w ramy konstrukcji datio in solutum podkreślano, że „z punktu widzenia konsekwencji podatkowych sytuacja jest taka sama, jak ta, w której spółka dokonałaby odpłatnego zbycia składników majątkowych, tym samym osiągnęłaby przychód do opodatkowania, a następnie środki pienięźne z tego zbycia przekazałaby uprawnionemu udziałowcowi"19. Wskazywano, że $d a$ tio in solutum jest formą spełnienia świadczenia, które dopiero w momencie jego wykonania będzie stanowiło przychód na podstawie art. 14a u.p.d.o.p. ${ }^{20}$. W tej grupie prezentowano także poglądy podkreślające, że art. 14a u.p.d.o.p. nie obejmuje swoim zakresem jedynie wykonania zobowiązania pieniężnego w formie datio in solutum, ponieważ przepis mówi o „regulowaniu” zobowiązania w formie niepieniężnej. Znajdzie on w związku z tym zastosowanie także w przypadku świadczeń niepieniężnych wykonywanych w celu uregulowania w całości lub części zobowiązań o określonej wysokości ${ }^{21}$. Ponadto

${ }^{17}$ Uzasadnienie Rząlowego projektu ustawy z dnia 14 kwietnia 2014 r. (druk nr 2330) o zmianie ustawy o podatku dochodowym od osób prawnych, ustawy o podatku dochodowym od osób fizycznych oraz o zmianie niektórych innych ustaw; dalej jako: „uzasadnienie”.

${ }^{18}$ Por. wyrok WSA w Gdańsku z dnia 8 lutego 2017 r., I SA/Gd 1218/16, Lex nr 2239245.

${ }^{19}$ Wyrok WSA w Białymstoku z dnia 23 listopada 2016 r., I SA/Bd 719/16, Lex nr 2228025.

${ }^{20}$ Wyrok WSA w Gliwicach z dnia 21 kwietnia 2016 r., I SA/Gl 1264/15, Lex nr 2059049.

${ }^{21}$ Wyrok Naczelnego Sądu Administracyjnego z dnia 27 czerwca 2017 r., II FSK 658/17, Lex nr 2351662. 
część składów podkreślała, że w wyniku likwidacji spółki powstaje zobowiązanie spółki do spełnienia świadczenia w formie wypłaty równowartości odpowiedniej części majątku w postaci kwoty pieniężnej lub poprzez wydanie określonego składnika majątku. W wyniku czynności przekazania majątku likwidowanej spółki natomiast nastąpi spełnienie zobowiązania spółki względem wspólnika ${ }^{22}$.

Zgodnie z drugim poglądem z kolei czynność wydania majątku polikwidacyjnego nie prowadzi do powstania przychodu po stronie spółki, ponieważ czynność ta nie stanowi realizacji stosunku zobowiązaniowego, w wyniku którego spółka osiągnie stanowiące przychód przysporzenie ${ }^{23}$. Jest to czynność odrębna, która ma miejsce już po uregulowaniu zobowiązań ciążących na spółce. Czynność wydania majątku wynika wprost z art. 286 k.s.h., nie z umowy o charakterze cywilnoprawnym. Po stronie spółki powstaje wprawdzie przysporzenie, jednak ma ono charakter jedynie korporacyjny, konieczny do wykreślenia spółki z rejestru ${ }^{24}$. Jest to czynność wyłącznie o charakterze technicznym, a nie stosunek umowny między wierzycielem a dłużnikiem ${ }^{25}$. W wyroku Naczelnego Sądu Administracyjnego z dnia 14 stycznia 2015 r. wskazano, że: ,,[p]rzekazanie majątku likwidowanej spółki wspólnikowi jest czynnością jednostronną, która nie nakłada na wspólnika obowiązku spełnienia świadczenia wzajemnego; wspólnik nie płaci też żadnej ceny"26. Kolejnym argumentem było wskazanie, że art. 286 k.s.h. mówi o „,podziale majątku między wspólników”, nie o wierzytelności i wierzycielach ${ }^{27}$.

Ponadto niektóre składy sędziowskie wskazywały, że zmiana legislacyjna wprowadzająca do u.p.d.o.p. art. 14a stanowiła całkowicie nowe uregulowanie ${ }^{28}$. Podkreślało to argumentację, że opodatkowanie datio in solutum nie wynika wprost $\mathrm{z}$ samego charakteru tej instytucji, w związku z czym nie może wynikać z ogólnej regulacji art. 12 u.p.d.o.p. czy

${ }^{22}$ Por. wyrok WSA we Wrocławiu z dnia 16 listopada 2015 r., I SA/Wr 1563/15, Lex nr 2042239.

${ }^{23}$ Wyrok WSA w Gdańsku z dnia 8 lutego 2017 r., I SA/Gd 1218/16, Lex nr 2239245.

${ }^{24}$ Wyrok WSA w Łodzi z dnia 19 kwietnia 2016 r., I SA/Łd 146/16, Lex nr 2023098.

${ }^{25} \mathrm{~J}$. Sekita, Towary lub usługi zamiast zapłaty. Wybrane problemy opodatkowania datio in solutum, „Przeglac Podatkowy” 2016, nr 1, s. 10.

${ }^{26}$ Wyrok Naczelnego Sacdu Administracyjnego z dnia 14 stycznia 2015 r., II FSK 2844/12, ONSAiWSA 2016, z. 3(51).

${ }^{27}$ J. Sekita, op. cit., s. 10.

${ }^{28}$ Wyrok Naczelnego Sądu Administracyjnego z dnia 1 czerwca 2017 r., II FSK 1220/15, Lex nr 2325336. 
interpretacji rozszerzającej art. 14a u.p.d.o.p. Datio in solutum stanowi bowiem czynność prawną jednostronną i nieodpłatną, ponieważ dokonując jej, spółka nie otrzymuje w zamian żadnego przysporzenia ${ }^{29}$. W związku z tym, że artykuł nie mówi wprost o wydaniu majątku polikwidacyjnego wspólnikom, równocześnie wypowiadając się o dywidendach czy umorzeniu udziałów, trudno stwierdzić, że racjonalny ustawodawca zapomniał o wymienieniu tych czynności w treści przepisu ${ }^{30}$.

W prowadzonej analizie warto także wskazać na tezę wyroku Naczelnego Sądu Administracyjnego z dnia 28 stycznia 2015 r., w którym sąd podkreślił, że „,w] orzecznictwie Naczelnego Sądu Administracyjnego utrwalił się pogląd, iż treść umowy cywilnoprawnej wywołuje skutek wyłącznie pomiędzy stronami tej umowy i nie może modyfikować treści obowiązku podatkowego, który jest stosunkiem administracyjnoprawnym między poszczególnymi podatnikami a budżetem państwa i kształtowany jest bezpośrednio przez normy prawa podatkowego" ${ }^{31}$. Na uwagę zasługuje również wyrok Wojewódzkiego Sądu Administracyjnego w Warszawie, w którym sąd wskazał, że art. 14a u.p.d.o.p. reguluje sytuacje, w których świadczenie niepieniężne spełniane jest w miejsce świadczenia pieniężnego, do którego to świadczenia podatnik był zobowiązany. W przypadku natomiast przekazania majątku polikwidacyjnego $\mathrm{w}$ formie rzeczowej nie można mówić o istnieniu zobowiązania, które miałoby swoją „,wysokość” i które można byłoby „regulować”32. Tym samym sąd stanął na stanowisku, że w tej sytuacji nie można mówić o możliwości wpisania niniejszej czynności w ramy konstrukcji datio in solutum.

Rozbieżność interpretacyjna pojawiła się także w zakresie uznania, czy art. 14a u.p.d.o.p. odnosi się także do sytuacji, w których pierwotna treść stosunku prawnego przewiduje niepieniężną formę świadczenia. Z jednej strony można uznać, że artykuł znajdzie w tej sytuacji zastosowanie, jeżeli tylko możliwe jest określenie wysokości regulowanego zobowiązania ${ }^{33}$.

${ }^{29}$ A. Kidyba, Komentarz aktualizowany do art. 1-300 Kodeksu spółek handlowych komentarz do art. 286 [online]. System Informacji Prawnej LEX [dostęp 6.07.2018].

${ }^{30}$ Wyrok WSA w Warszawie z dnia 23 sierpnia 2017 r., III SA/Wa 2976/16, Lex nr 2375928.

${ }^{31}$ Por. wyrok Naczelnego Sadu Administracyjnego z dnia 28 stycznia 2015 r., II FSK 2083/13, Lex nr 1646209; wyrok Naczelnego Sacu Administracyjnego z dnia 20 maja 1999 r., sygn. akt III SA 5036/98, Lex nr 40952.

${ }^{32}$ Wyrok WSA w Warszawie z dnia 22 listopada 2017 r., III SA/Wa 2630/16, Lex nr 2447188.

${ }^{33}$ Wyrok Naczelnego Sądu Administracyjnego z dnia 27 czerwca 2017 r., II FSK 658/17, Lex nr 2351662. 
Z drugiej strony w takiej sytuacji zasadniczo wykonanie jakiegokolwiek świadczenia niepieniężnego prowadziłoby po stronie wykonawcy do powstania przychodu, natomiast celem regulacji było zrównanie sytuacji osób spełniających świadczenia w formie pieniężnej i niepieniężnej ${ }^{34}$.

Podsumowując tę analizę, należy stwierdzić, że zagadnienie skutków podatkowych czynności wydania majątku polikwidacyjnego w formie rzeczowej po stronie spółki budzi liczne wątpliwości.

Podstawową wątpliwość stanowi uznanie, czy datio in solutum może prowadzić do powstania przychodu po stronie wykonującego świadczenie. Każda ze stron posiada argumenty, które zasługują na uwagę. Rzeczywiście, wątpliwość może budzić opodatkowanie datio in solutum, gdy spojrzymy na tę konstrukcję jako na konstrukcję ściśle wiążącą wygaśnięcie zobowiązania z zaspokojeniem wierzyciela o charakterze odpłatnym. Formułując zagadnienie w ten sposób, przychodem wydaje się być wygaśnięcie zobowiązania, co jawi się jako wniosek nieprzekonujący. Ponadto wątpliwość budzi powstanie przychodu po obu stronach czynności, w szczególności w sytuacji, gdy spojrzymy na tę konstrukcję jako na czynność jednostronną. Z drugiej strony, jeżeli, tak jak wskazuje strona uznająca, czynność ta prowadzi do powstania przychodu po stronie spełniającego świadczenie, zauważymy, że w sytuacji gdyby podmiot regulujący zobowiązanie chciał je spełnić w formie pieniężnej, musiałby wcześniej sprzedać dany składnik, doprowadzając do powstania po swojej stronie przychodu. Wydaje się, że logiczne jest mówienie o powstaniu przychodu po stronie wykonującego świadczenie.

W celu rozwiania wątpliwości opodatkowania datio in solutum po stronie spełniającego świadczenie, ustawodawca wprowadził do u.p.d.o.p. art. 14a. Zmiana ta nie doprowadziła jednak do rozwiania wątpliwości interpretacyjnych, ponieważ artykuł nie mówił wprost o wydaniu majątku polikwidacyjnego. Wydaje się w związku z tym, że tak jak w poprzednim stanie prawnym wątpliwości niektórych budziła sama możliwość opodatkowania datio in solutum po stronie spełniającego świadczenie, ponieważ nie akceptowali oni tezy o powstaniu przychodu po stronie spełniającego świadczenie niepieniężne, tak w sytuacji, gdy artykuł nie mówi wprost o tej czynności, opór budzi wpisanie jej w ramy regulacji art. 14a u.p.d.o.p. Opór ten można uznać za uzasadniony, jeśli uzna się, że opodatkowanie

${ }^{34}$ W. Majkowski, M. Michna, Wydanie wspólnikom majątku w postaci rzeczowej przez spółkę kapitałową w likwidacji, „Przegląd Podatkowy” 2017, nr 10, s. 25. 
tej czynności nie wynika z samego jej charakteru oraz gdy zauważy się, że mimo iż ustawodawca pisał o likwidacji spółki w uzasadnieniu do art. 14a u.p.d.o.p., to nie zawarł o niej wzmianki w przepisie wymieniającym szereg innych tytułów. Warto także wskazać, że przepisy ustaw podatkowych mówią wprost o powstaniu przychodu po stronie wspólnika otrzymującego majątek polikwidacyjny. Tym bardziej wzmacnia to argumentację, zgodnie z którą ustawodawca jednak nie dążył do opodatkowania przedmiotowej czynności po stronie spółki.

Wczytując się natomiast $\mathrm{w}$ brzmienie art. 14a, należy zwrócić uwagę na zwrot „wysokość zobowiązania uregulowanego w następstwie takiego świadczenia”. Wydaje się, że w prawie cywilnym rozróżnia się raczej „wysokość świadczenia” - która odnosi się do świadczeń pieniężnych, oraz „wartość świadczenia” - odnoszącą się do świadczeń niepieniężnych. Zobowiązanie należy zaś rozumieć jako węzeł prawny łączący strony stosunku cywilnoprawnego. Ponadto datio in solutum prowadzi do zmiany treści zobowiązania, czyli zmiany treści stosunku prawnego. Wątpliwe więc wydaje się mówienie o wysokości zobowiązania uregulowanego tym świadczeniem.

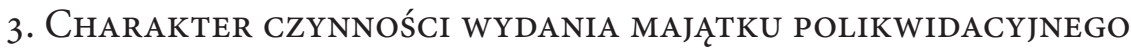

W ŚWIETLE PRAWA HANDLOWEGO

Czynność wydania majątku polikwidacyjnego stanowi element upłynnienia majątku spółki i należy do czynności likwidacyjnych sensu stricto $^{35}$. Czynności likwidacyjne są przeprowadzane przez likwidatorów spółki, do których zgodnie z art. 282 ustawy z dnia 15 września 2000 r. - Kodeks spółek handlowych ${ }^{36}$ należy zakończenie interesów bieżących spółki, ściągnięcie wierzytelności, wypełnienie zobowiązań i upłynnienie majątku spółki. Likwidatorzy zobowiązani są do zaspokojenia albo zabezpieczenia wszystkich wierzytelności. Przed spłatą wszystkich zobowiązań nie można wypłacać wspólnikom żadnych zysków ani dokonywać podziału majątku spółki. Dopiero wykonanie czynności przewidzianych w art. 282 k.s.h. umożliwia podział majątku spółki zgodnie z art. 286 k.s.h. ${ }^{37}$. Majątek

${ }^{35}$ J. Naworski, Komentarz do art. 286, [w:] T. Siemiatkowski, R. Potrzeszcza, Kodeks spółek handlowych. Komentarz. Tytuł III. Spółki kapitałowe. Dział I. Spółka z ograniczona odpowiedzialnościa。 Warszawa 2011, s. 648.

${ }^{36}$ Dz.U. z 2017 r., poz. 1577 z późn. zm.; dalej: k.s.h.

${ }^{37}$ Postanowienie Sądu Najwyższego z dnia 20 września 2007 r., II CSK 240/07, Lex nr 487505. 
polikwidacyjny, czyli składniki pozostałe po przeprowadzeniu likwidacji, jest dzielony między wspólników, tym kończy się likwidacja spółki sensu stricto $^{38}$.

W związku z powyższym należy zauważyć, że zgodnie z k.s.h. spółka zobowiązana jest najpierw do zaspokojenia lub zabezpieczenia roszczeń wszystkich wierzycieli. W tym przypadku nie budzi wątpliwości charakter tej czynności jako czynności spełnienia zobowiązania spółki względem jej wierzycieli. K.s.h. wprost posługuje się terminem „wypełniania zobowiązań”.

W przypadku wydania majątku polikwidacyjnego natomiast, w tym w formie rzeczowej, kodeks posługuje się sformułowaniem ,,podziału majątku”. Czy w tej sytuacji można mówić jednak o spełnieniu przez spółkę zobowiązania ciążącego na niej w stosunku do wspólników?

Pojęcie zobowiązania zdefiniowane jest w art. 353 k.c. Zgodnie z przedmiotową regulacją zobowiązanie polega na tym, że wierzyciel może żądać od dłużnika świadczenia, a dłużnik powinien świadczenie spełnić. Za podstawowy element treści zobowiązania należy uznać wierzytelność, czyli możliwość żądania od dłużnika świadczenia ${ }^{39}$.

Art. 286 k.s.h. dotyczy podziału majątku spółki, wskazując, że następuje on po zaspokojeniu lub zabezpieczeniu wierzycieli. Podziałowi między wspólników podlega kwota likwidacyjna, czyli wartość wynikająca ze sprawozdania finansowego. Podział majątku polikwidacyjnego może nastąpić w przeciągu 6 miesięcy od ogłoszenia o otwarciu likwidacji w „Monitorze Sądowym i Gospodarczym”. Właścicielami majątku polikwidacyjnego są wspólnicy ${ }^{40}$.

Pozostały w spółce majątek dzielony jest w stosunku do udziałów posiadanych przez wspólników. Zasadą jest wypłata stosownego udziału w nadwyżce majątkowej, ponieważ art. 282 mówi o tym, że likwidatorzy mają obowiązek upłynnić majątek spółki. Upłynnienie majątku spółki służy dokonaniu rozliczeń z wierzycielami. Podział majątku w formie pieniężnej ułatwia sprawiedliwy podział jego składników ${ }^{41}$, jednak możliwe jest także dokonanie podziału poprzez wydanie poszczególnych

${ }^{38}$ W. Missala, Ł. Wolbach, Czynności likwidacyjne, [w:] W. Missala, Likwidacja spółki kapitałowej. Prawo, podatki, rachunkowość, Warszawa 2013, s. 114-115.

${ }^{39}$ A. Olejniczak, Art. 353, [w:] A. Kidyba, Kodeks cywilny. Komentarz. Tom III. Zobowiązania - część ogólna, wyd. II, Warszawa 2010, s. 22.

${ }^{40}$ W. Missala, Ł. Wolbach, op. cit., s. 114-115.

${ }^{41}$ M. Litwińska-Werner, Kodeks spółek handlowych. Komentarz, Warszawa 2007, s. $722-723$. 
jego składników w formie rzeczowej. Warto w tym miejscu wskazać, że $\mathrm{w}$ praktyce w majątku likwidowanej spółki przed jego podziałem pomiędzy wspólników znajdują się z reguły nie tylko kwoty pieniężne, ale też składniki rzeczowe. W takiej sytuacji składniki te powinny zostać upłynnione bądź wydane $\mathrm{w}$ formie rzeczowej. W doktrynie podkreśla się, że jest to możliwe pod warunkiem, że wszyscy wspólnicy wyrażą zgodę na to, żeby spółka zamiast wypłacać im kwotę likwidacyjną, spełniła inne świadczenie ${ }^{42}$. M. Rodzynkiewicz wskazuje, że „,[n]ie można [...] wykluczyć świadczeń w naturze za porozumieniem stron, a w szczególności w drodze datio in solutum". Podział pozostałego majątku w naturze może wynikać także z zapisów umowy spółki (art. $286 \$ 3)^{43}$. W tym miejscu warto wspomnieć, że konstrukcja datio in solutum budzi poważne wątpliwości interpretacyjne w doktrynie prawa cywilnego, jest uważana za zbyt wyabstrahowaną, stwarzającą poważne trudności w stosowaniu jej w praktyce ${ }^{44}$. Wątpliwość budzi m.in. uznanie, czy w przypadku datio in solutum mamy do czynienia ze zmianą treści pierwotnego zobowiązania ${ }^{45}$. Przykładowo, F. Zoll wskazuje, że konstrukcja ta nie prowadzi do modyfikacji treści samego zobowiązania, a jedynie zmienia sam sposób spełnienia świadczenia ${ }^{46}$. M. Berek wskazuje natomiast, że na instytucję datio in solutum składają się dwa kluczowe elementy, które muszą występować łącznie: zmiana treści zobowiązania w zakresie należnego wierzycielowi przedmiotu świadczenia oraz spełnienie przez dłużnika świadczenia zastępczego ${ }^{47}$. Autor podaje przykład, w którym wskazuje, że w sytuacji, gdy „pożyczkobiorca sumy pieniężnej przenosi na pożyczkodawcę własność rzeczy, pactum de in solutum dando polega na zmianie treści stosunku prawnego w sposób rodzący zobowiązanie dłużnika do przeniesienia własności rzeczy"48.

${ }^{42}$ E. Mentel-Wyrzychowska, Podział w naturze majątku likwidowanej spółki z o.o., „Gazeta Podatkowa” 2013, nr 39(976), s. 17.

${ }^{43}$ M. Rodzynkiewicz, Kodeks spółek handlowych. Komentarz, wyd. 5, Warszawa 2013, s. 542 .

${ }^{44}$ F. Zoll, Świadczenie w miejsce wykonania, [w:] M. Pecyna, Wykonanie i skutki naruszenia zobowiązań. Projekt z uzasadnieniem, Kraków 2009, s. 198-201.

${ }^{45}$ M. Berek, Datio in solutum w polskim prawie cywilnym, „Kwartalnik Prawa Prywatnego" 2012, nr 3, s. 654-656.

${ }^{46}$ F. Zoll, op. cit., s. 201.

${ }^{47}$ M. Berek, op. cit., s. 685.

${ }^{48}$ Ibidem, s. 674-675. 
Podsumowując tę część rozważań, należy stwierdzić, że przepisy k.s.h. zawierają dość ogólne regulacje dotyczące kwestii podziału majątku spółki między jej wspólników. K.s.h. w art. 286 posługuje się sformułowaniem „,podziału majątku”. Odczytując te regulacje wespół z art. 282 k.s.h., można wnioskować, że zasadą jest podział majątku po jego upłynnieniu, możliwe jest jednak dokonanie podziału w formie rzeczowej. Doktryna podkreśla, że w przypadku wydania majątku w formie rzeczowej z reguły ujmuje się tę czynność w ramy konstrukcji datio in solutum ${ }^{49}$. W związku z częściowo dyspozytywnym chrakterem art. 282 k.s.h. umowa spółki może jednak przewidywać także inną formę rozliczenia ${ }^{50}$.

W związku z tym, że majątek polikwidacyjny stanowi własność wspólników spółki, wydaje się, że można mówić o istnieniu stosunku zobowiązaniowego pomiędzy spółką a wspólnikami. Spółkę łączy węzeł prawny ze wspólnikiem, polegający na tym, że wspólnik (wierzyciel) może żądać od spółki (dłużnika) świadczenia, czyli wydania majątku polikwidacyjnego. Jak wskazuje P. Antoszek: „W stosunkach wewnętrznych spółki kapitałowej spełniona jest jedna $\mathrm{z}$ najistotniejszych cech stosunku cywilnoprawnego, za którą uznaje się brak prawnej kompetencji jednego podmiotu prawa cywilnego do jednostronnego kształtowania sytuacji prawnej drugiego podmiotu"51. O autonomii wspólników świadczy także fakt, że to do nich należy decyzja o tym, w jakiej formie chcą przyjąć dzielony majątek spółki.

Odnosząc powyższe do zagadnienia podatkowych skutków wydania majątku polikwidacyjnego po stronie spółki, wydaje się, że w świetle przepisów k.s.h. można mówić, że wydając wspólnikom majątek polikwidacyjny, spółka spełnia względem nich świadczenie wynikające z łączącego ich stosunku zobowiązaniowego. Wątpliwe wydaje się przypisywanie tej czynności charakteru jedynie technicznego.

Tak jak wspomniano wcześniej, podział majątku polikwidacyjnego pomiędzy wspólników może natomiast wystąpić zarówno w formie pieniężnej, jak i niepieniężnej. W przypadku wydania majątku w formie niepieniężnej podstawą tej czynności może być umowa spółki bądź datio in solutum. Jeżeli nastąpi to $\mathrm{w}$ formie datio in solutum, następuje uregulowanie

${ }^{49}$ Por. M. Rodzynkiewicz, op. cit., s. 542-543; A. Kidyba, K. Kopaczyńska-Pieczniak, Spółka z ograniczoną odpowiedzialnościa, Warszawa 2013, s. 426.

${ }^{50}$ A. Kidyba, K. Kopaczyńska-Pieczniak, op. cit., s. 426.

${ }^{51} \mathrm{P}$. Antoszek, Cywilnoprawny charakter uchwał wspólników spółek kapitałowych, Warszawa 2009, s. 192. 
zobowiązania pierwotnie pieniężnego w formie niepieniężnej. W przypadku natomiast, gdy umowa spółki przewiduje wydanie składników majątku polikwidacyjnego $\mathrm{w}$ formie niepieniężnej, wyłączając z zakresu czynności likwidacyjnych upłynnienie majątku spółki, regulowane zobowiązanie od początku ma charakter niepieniężny ${ }^{52}$.

\section{RACHUNKOWOŚĆ LIKWIDOWANEJ SPÓ£KI}

Do istotnych przepisów regulujących wydanie majątku polikwidacyjnego spółki z o.o. należy zaliczyć art. 5 ust. 2, art. 12 ust. 1 pkt 5, art. 12 ust. 2 pkt 2 , art. 12 ust. 2 pkt 6 , art. 29 ust. 2 a, art. 36 ust. 3 , art. 45 ust. 1 oraz art. 76 ust. 1 pkt 2 ustawy z dnia 29 września 1994 r. o rachunkowości ${ }^{53}$.

Na dzień poprzedzający dzień postawienia jednostki w stan likwidacji zamyka się księgi rachunkowe ${ }^{54}$, zostają one otwarte $\mathrm{w}$ dniu rozpoczęcia likwidacji ${ }^{55}$, jest to pierwszy dzień nowego roku obrotowego. W tym przypadku otwierając księgi rachunkowe, należy sporządzić bilans otwarcia, w którym wartości aktywów wycenia się według cen sprzedaży możliwych do uzyskania, a zobowiązania według wartości podlegającej zapłacie ${ }^{56}$. Spółka postawiona w stan likwidacji jest zobowiązana sporządzić sprawozdanie finansowe ${ }^{57}$.

Sprawozdanie likwidacyjne podsumowujące przeprowadzoną likwidację jest sporządzane bezpośrednio przed dokonaniem podziału między wspólników albo akcjonariuszy majątku spółki, który pozostał po zaspokojeniu lub zabezpieczeniu wierzycieli ${ }^{58}$. Sprawozdanie likwidacyjne jest sprawozdaniem finansowym, wyróżnianym z uwagi na szczególny moment jego sporządzenia. Służy ono m.in. wykazaniu niespłaconych i niezabezpieczonych zobowiązań spółki; pozwala także wykazać, jakie aktywa pozostały do podziału między wspólników. Podlega ono zatwierdzeniu. Likwidator składa organowi podatkowemu sprawozdanie finansowe ${ }^{59}$ wraz

\footnotetext{
${ }^{52}$ Podobnie: W. Majkowski, M. Michna, op. cit., s. 28.

${ }^{53}$ Dz.U. z 2018 r., poz. 395 z późn. zm.; dalej: ,,ustawa o rachunkowości”.

${ }^{54}$ Art. 12 ust. 2 pkt 6 ustawy o rachunkowości.

${ }^{55}$ Art. 12 ust. 1 pkt 5 ustawy o rachunkowości.

${ }^{56}$ A. Helin, Ustawa o rachunkowości. Komentarz, Warszawa 2012, s. 133.

${ }^{57}$ Art. 45 ust. 1 ustawy o rachunkowości.

${ }^{58}$ Art. $286 \$ 1$ k.s.h.

${ }^{59}$ Art. 290 k.s.h., możliwość złożenia odpisów.
} 
z zeznaniami podatkowymi spółki oraz zawiadamia o zakończeniu postępowania likwidacyjnego ${ }^{60}$.

Po podziale majątku między wspólników należy sporządzić sprawozdanie finansowe na dzień zakończenia likwidacji. Końcową czynnością jest złożenie wniosku o wykreślenie spółki z Krajowego Rejestru Sądowego na formularzu KRS-X2 do sądu rejestrowego. Do wniosku należy dołączyć sprawozdanie likwidacyjne, sprawozdanie finansowe na dzień zakończenia likwidacji, protokół potwierdzający ich zatwierdzenie przez zgromadzenie wspólników oraz oświadczenie likwidatorów o ogłoszeniu obu sprawozdań w siedzibie spółki. Wykreślenie spółki z rejestru ma charakter konstytutywny ${ }^{61}$.

Konkludując, podział majątku polikwidacyjnego między wspólników wyznacza moment sporządzenia dwóch sprawozdań finansowych: sprawozdania likwidacyjnego oraz sprawozdania na dzień zakończenia likwidacji. Ponadto należy zauważyć, że w bilansie otwarcia, a także w sprawozdaniu finansowym określa się szczegółowo wartość posiadanego przez spółkę majątku. Konieczne jest wskazanie m.in. wartości aktywów trwałych. Znana jest także wartość majątku polikwidacyjnego. W związku z tym wydaje się, że możliwe jest określenie wartości otrzymywanego przez wspólników świadczenia - zarówno w przypadku, gdy będzie miało formę pieniężną, jak i niepieniężną.

5. WNIOSKI

Istnieją liczne argumenty pozwalające na uznanie, że wydanie przez spółkę polikwidacyjnego majątku jej wspólnikom prowadzi do powstania po jej stronie przychodu na kanwie art. 14a u.p.d.o.p. Nie są one jednak w pełni przekonujące i pozostaje pole do argumentacji wskazującej na to, że wydanie majątku polikwidacyjnego nie prowadzi do powstania żadnego przysporzenia po stronie spółki. W związku $z$ istnieniem poważnych rozbieżności $\mathrm{w}$ orzecznictwie sądów administracyjnych $\mathrm{w}$ przedmiocie uznania, czy wydanie majątku polikwidacyjnego wspólnikom w formie rzeczowej prowadzi do powstania po stronie spółki przychodu, konieczne jest zdaniem autorki tego tekstu odwołanie się do zasady in dubio pro tributario.

${ }^{60}$ W. Missala, Ł. Wolbach, op. cit., s. 113.

${ }^{61}$ A. Witosz, Rozwiązanie i likwidacja spółek handlowych, Warszawa 2011, s. 182. 
W ostatnim wyroku Trybunału Konstytucyjnego zaznaczono: „W wypadku gdy po starannej aplikacji językowych dyrektyw wykładni oraz - ewentualnym - odrzuceniu tych wariantów interpretacyjnych, które nie spełniają wymogów systemowych, interpretator nie uzyskał jednoznaczności poddanej wykładni regulacji daninowej, spośród możliwych rezultatów interpretacyjnych, musi dokonać wyboru rezultatu najbardziej korzystnego z punktu widzenia sytuacji prawnej podatnika lub innego podmiotu obowiązanego do świadczenia daniny publicznoprawnej"62. Należy ponadto wskazać na regulację zawartą w art. 217 Konstytucji Rzeczypospolitej Polskiej z dnia 2 kwietnia 1997 r. ${ }^{63}$ Stanowi ona gwarancję określenia podmiotu, przedmiotu i stawek podatkowych na poziomie ustawowym, tym samym zapewniając, że akt podustawowy ani interpretacja przepisu ustawy podatkowej nie będą mogły być na tyle swobodne, by zmieniły na niekorzyść czyjąkolwiek sytuację prawnopodatkową ${ }^{64}$.

Analiza orzecznictwa sądów administracyjnych prowadzi do wniosku, że większość ze składów popierająca tezę, że art. 14a u.p.d.p.o.p. obejmuje swoim zakresem wydanie majątku polikwidacyjnego spółki w formie rzeczowej, w największym stopniu opierała swoje rozumowanie na zapisach uzasadnienia ustawy. Należy to uznać za przejaw nieuprawnionej wykładni funkcjonalnej na niekorzyść podatnika. W procesie wykładni uregulowań sądy powinny w szczególności zauważyć poważne wątpliwości interpretacyjne rodzące się na tle tego zagadnienia (zarówno w obszarze wykładni językowej, jak i systemowej) oraz związaną z tym faktem niepewność podatnika co do treści przepisów prawa. Biorąc pod uwagę, że zagadnienie to prowadzi do wysuwania odmiennych wniosków przez różne składy wojewódzkich sądów administracyjnych, jak i Naczelnego Sądu Administracyjnego, wydaje się być w pełni uzasadnione mówienie o „niedających się usunąć wątpliwościach co do treści przepisów prawa podatkowego", i w związku z tym o konieczności rozstrzygnięcia tych wątpliwości na korzyść podatnika.

Zdaniem autorki, w celu rozstrzygnięcia poważnych wątpliwości interpretacyjnych związanych $\mathrm{z}$ art. 14 u.p.d.o.p. właściwe byłoby, żeby legislator uściślił brzmienie przedmiotowej regulacji, ostatecznie

${ }^{62}$ Wyrok Trybunału Konstytucyjnego z dnia 13 grudnia 2017 r., SK 48/15, OTK-A 2018/2.

${ }^{63}$ Dz.U. 1997 r. Nr 78, poz. 483 z późn. zm.

${ }^{64}$ T. Dębowska-Romanowska, Dylematy interpretacyjne artykułu 2017 Konstytucji, [w:] A. Gomułowicz, J. Małecki, Ex iniuria non oritur ius, Poznań 2003, s. 220. 
rozstrzygając, czy czynność wydania majątku polikwidacyjnego $\mathrm{w}$ formie rzeczowej prowadzi do powstania przychodu po stronie spółki. W obecnym stanie prawnym nie jest możliwe udzielenie jednoznacznej odpowiedzi na to pytanie. Ponadto analiza przedmiotowej czynności z punktu widzenia prawa handlowego, jak i przepisów dotyczących rachunkowości, prowadzi do wniosku, że tak ustawodawca, jak i sądy administracyjne często błędnie interpretują pojęcia $\mathrm{z}$ tych dziedzin prawa. W sytuacji więc, gdy ustawodawca nie reguluje znaczenia danych pojęć na potrzeby ustaw podatkowych i konieczne jest odwoływanie się do innych dziedzin prawa regulujących tę materię, niezbędne jest dokładne zrozumienie mechanizmów rządzących tymi dziedzinami. Może to prowadzić do powstania poważnych trudności, ponieważ zasady wynikające $\mathrm{z}$ innych dziedzin prawa mogą być interpretowane przez osoby zajmujące się prawem podatkowym ogólnikowo i bez zrozumienia bądź rodzić poważne wątpliwości interpretacyjne nawet wśród przedstawicieli doktryny ${ }^{65}$. W związku z tym w sytuacji, gdy wątpliwości wywołuje interpretacja pojęć z innych dziedzin prawa, uzasadniona wydaje się próba ich interpretacji w ogólnych ramach prawa podatkowego, w obrębie których kluczowa jest identyfikacja przychodu ${ }^{66}$.

\section{BIBLIOGRAFIA}

Antoszek P., Cywilnoprawny charakter uchwał wspólników spółek kapitałowych, Warszawa 2009.

Berek M., Datio in solutum w polskim prawie cywilnym, „Kwartalnik Prawa Prywatnego” 2012 , nr 3.

Dębowska-Romanowska T., Dylematy interpretacyjne artykułu 2017 Konstytucji, [w:] A. Gomułowicz, J. Małecki, Ex iniuria non oritur ius, Poznań 2003.

Helin A., Ustawa o rachunkowości. Komentarz, Warszawa 2012.

${ }^{65} \mathrm{Na}$ marginesie warto wspomnieć, że omawiane zagadnienie może stanowić interesujący przedmiot rozważań na kanwie problematyki autonomii prawa podatkowego. Wyniki analizy skłaniają do wysunięcia postulatu, żeby ustawodawca tworząc przepisy prawa podatkowego, w jak największym stopniu poruszał się w obrębie pojęć i zasad wypracowanych $w$ ramach prawa podatkowego, co pozwoli uniknąć możliwych trudności interpretacyjnych związanych $\mathrm{z}$ analizą pojęć $\mathrm{z}$ innych dziedzin prawa.

${ }^{66}$ Zdaniem autorki, $\mathrm{w}$ analizowanym przypadku, w związku z niejednoznacznością regulacji z art. 14a u.p.d.o.p., istotne jest jej ujęcie w świetle ogólnych zapisów u.p.d.o.p. odnoszących się do pojęcia przychodu oraz skupienie się na odpowiedzi na pytanie o możliwość identyfikacji przysporzenia po stronie spółki spełniającej świadczenie względem wspólnika. 
Kidyba A., Komentarz aktualizowany do art. 1-300 Kodeksu spółek handlowych. Komentarz do art. 286 [online]. System Informacji Prawnej LEX.

Kidyba A., Kopaczyńska-Pieczniak K., Spółka z ograniczoną odpowiedzialnością, Warszawa 2013.

Konstytucja Rzeczypospolitej Polskiej z dnia 2 kwietnia 1997 r. (Dz.U. 1997 r. Nr 78, poz. 483 z późn. zm.).

Litwińska-Werner M., Kodeks spółek handlowych. Komentarz, Warszawa 2007.

Majkowski W., Michna M., Wydanie wspólnikom majątku w postaci rzeczowej przez spótkę kapitałowa w likwidacji, „Przegląd Podatkowy” 2017, nr 10.

Mentel-Wyrzychowska E., Podział w naturze majątku likwidowanej spółki z o.o., „Gazeta Podatkowa” 2013, nr 39(976).

Missala W., Wolbach Ł., Czynności likwidacyjne, [w:] W. Missala, Likwidacja spółki kapitałowej. Prawo, podatki, rachunkowość, Warszawa 2013.

Naworski J., Komentarz do art. 286, [w:] T. Siemiątkowski, R. Potrzeszcza, Kodeks spółek handlowych. Komentarz. Tytuł III. Spółki kapitałowe. Dział I. Spółka z ograniczong odpowiedzialnością, Warszawa 2011.

Olejniczak A., Art. 353, [w:] A. Kidyba, Kodeks cywilny. Komentarz. Tom III. Zobowiązania - część ogólna, wyd. II, Warszawa 2010.

Rodzynkiewicz M., Kodeks spółek handlowych. Komentarz, wyd. 5, Warszawa 2013.

Sekita J., Towary lub ustugi zamiast zapłaty. Wybrane problemy opodatkowania datio in solutum, „Przegląd Podatkowy” 2016, nr 1.

Witosz A., Rozwiązanie i likwidacja spółek handlowych, Warszawa 2011.

Zoll F., Świadczenie w miejsce wykonania, [w:] M. Pecyna, Wykonanie i skutki naruszenia zobowiązań. Projekt z uzasadnieniem, Kraków 2009.

\section{ISSUE OF LIMITED LIABILITY COMPANY'S POST LIQUIDATION ASSETS PARTITION WITH A PARTICULAR EMPHASIS ON THE QUESTION OF ITS COMPONENTS NON-CASH DISTRIBUTION IN THE LIGHT OF TAX LAW}

Summary. The article concerns a comprehensive analysis of the distribution of post-liquidation assets among its shareholders, with particular emphasis on the issue of non-cash distribution. The author wishes to present the title subject in a comprehensive manner, therefore the article presents how the concerned matter has been regulated in commercial law, in accounting regulations and in tax law. The regulation of this issue creates particularly serious problems in tax law, causing significant interpretative doubts, whether a distribution of post-liquidation assets in non-cash form generates revenue at the level of a company. Therefore, in summary it is worth considering whether in the light of tax law identification of the revenue on the side of the company is justified in such a situation.

Keywords: corporate income tax, liquidation of corporation, non-cash distribution. 